\title{
Effect of copper addition on glass transition of silicate-phosphate glasses
}

\author{
Justyna Sułowska - Irena Wacławska • \\ Magdalena Szumera
}

Bretsznajder Special Chapter

(C) The Author(s) 2012. This article is published with open access at Springerlink.com

\begin{abstract}
Glass transformation effect of mixed $\mathrm{SiO}_{2-}$ $\mathrm{P}_{2} \mathrm{O}_{5}-\mathrm{K}_{2} \mathrm{O}-\mathrm{MgO}-\mathrm{CaO}-\mathrm{CuO}$ glasses was studied by DSC, $\mathrm{XRD}$, SEM, and Raman spectroscopy methods. The relationship between the parameters characterizing glass transformation effect and an amount of phosphorous and copper forming the glassy structure was discussed. It was shown that an increasing content of phosphorous increased solubility of copper in the structure of the studied glasses which was the result of $\mathrm{P}-\mathrm{O}-\mathrm{Cu}$ bonds formation. Degree of changes of $T_{\mathrm{g}}, \Delta c_{\mathrm{p}}$, and time of relaxation values were higher in glasses with higher content of $\mathrm{P}_{2} \mathrm{O}_{5}$ and $\mathrm{CuO}$. The observed relations were explained on the basis of the local atomic interactions in the structure of glass.
\end{abstract}

Keywords Glass transformation - Silicate-phosphate glass $\cdot \mathrm{CuO}$

\section{Introduction}

Vitreous substances during heating and cooling exhibit glass transformation effect which is induced by relaxation of strains being the consequence of disordered arrangement of atoms forming glass structure. The relaxation of strains in the glass structure taking place at transformation temperature $\left(T_{\mathrm{g}}\right)$ is related to a change of such properties as heat capacity, linear and volume expansion coefficients, and viscosity. Parameters characterizing the glass transformation effect

J. Sułowska $(\bowtie) \cdot$ I. Wacławska $\cdot$ M. Szumera

Faculty of Materials Science and Ceramics, AGH University

of Science and Technology, Mickiewicza 30,

30-059 Cracow, Poland

e-mail: sulowska@agh.edu.pl depend on the nature and the number of components forming the glassy structure.

Copper may exist in glass at different oxidation states namely in the form of $\mathrm{Cu}^{2+}, \mathrm{Cu}^{+}$, and $\mathrm{Cu}^{0}$. This element is one of the glass structure modifiers. However, the introduction of excessive amount of copper into glass structure or wrong proportions of copper in relation to other components may facilitate crystallization of formed melt.

According to the literature glasses from $(50-x / 2) \mathrm{Na}_{2} \mathrm{O}-$ $x \mathrm{CuO}-(50-x / 2) \mathrm{P}_{2} \mathrm{O}_{5}$ system, where $x$ is less than $34 \mathrm{~mol} \%$ [1], as well as glasses from $50 \mathrm{P}_{2} \mathrm{O}_{5}-20 \mathrm{Na}_{2} \mathrm{O}-30 \mathrm{CuO}$ system [2] were totally amorphous. For glasses from $\mathrm{P}_{2} \mathrm{O}_{5}$ $\mathrm{Na}_{2} \mathrm{O}-\mathrm{CuO}$ system the glass formation region was determined as $\mathrm{P}_{2} \mathrm{O}_{5} \geq 40, \mathrm{CuO} \leq 50$, and $\mathrm{Na}_{2} \mathrm{O} \leq 60 \mathrm{~mol} \%$ [3]. Almost all glasses from $x \mathrm{Cu}_{2} \mathrm{O}-y \mathrm{P}_{2} \mathrm{O}_{5}-z \mathrm{MoO}_{3}$ system, where $x, y$, and $z$ changed from 0 to $50 \mathrm{~mol} \%$ were characterized by high glass forming ability with the exception of glasses with low $\mathrm{P}_{2} \mathrm{O}_{5}$ content where the ratio of $\mathrm{Cu}_{2} \mathrm{O} /$ $\mathrm{MoO}_{3}$ was equal to unity because during cooling of their melt crystallized molybdates such as $\mathrm{Cu}_{2} \mathrm{MoO}_{4}$ and $\mathrm{Cu}_{2} \mathrm{Mo}_{2} \mathrm{O}_{7}$ [4]. Glasses from $(0.70-x) \mathrm{SiO}_{2}-0.30 \mathrm{Na}_{2} \mathrm{O}-$ $x \mathrm{CuO}$ system where $x$ changed from 0 to $0.2 \mathrm{~mol} \%$ were completely amorphous [5]. In the case of glasses from $\mathrm{B}_{2} \mathrm{O}_{3}-\mathrm{SiO}_{2}-\mathrm{Al}_{2} \mathrm{O}_{3}-\mathrm{CaO}-\mathrm{CuO}$ system boron oxide increased solubility of $\mathrm{CuO}$ in their structure. $15 \mathrm{~mol} \%$ of $\mathrm{B}_{2} \mathrm{O}_{3}$ and $15-25 \mathrm{~mol} \%$ of $\mathrm{CuO}$ in their structure caused crystallization of fine-needle $\mathrm{CuO}$ crystals during their synthesis. However, if $\mathrm{B}_{2} \mathrm{O}_{3}$ content was greater than $20 \mathrm{~mol} \%$ these glasses did not show any tendency to crystallize during the synthesis [6].

In the literature, we can find information on the effect of copper on the glass transition effect of phosphate and silicate glasses. It was found that addition of increasing amount of $\mathrm{CuO}$ at the cost of $\mathrm{NaO}$ and $\mathrm{P}_{2} \mathrm{O}_{5}$ in structure of glasses from $(50-x / 2) \mathrm{Na}_{2} \mathrm{O}-x \mathrm{CuO}-(50-x / 2) \mathrm{P}_{2} \mathrm{O}_{5}$ system, where $x$ is less than $34 \mathrm{~mol} \%$ [1], as well as glasses from 
$\mathrm{P}_{2} \mathrm{O}_{5}-\mathrm{Na}_{2} \mathrm{O}-\mathrm{CuO}$ system [3] caused increase of the glass transition temperature $T_{\mathrm{g}}$ due to depolimeryzation of the glass network on smaller units which in turn combined by $\mathrm{P}-\mathrm{O}-\mathrm{Cu}$ bonds and resulted in an increase of crosslinking density of the glasses. According to the literature the ratio of $\mathrm{Cu}^{2+}$ ions to total amount of copper ions in the structure of glasses from $50 \mathrm{P}_{2} \mathrm{O}_{5}-20 \mathrm{Na}_{2} \mathrm{O}-30 \mathrm{CuO}$ [2] and $\mathrm{xCuO}-$ $(1-x) \mathrm{P}_{2} \mathrm{O}_{5}(0 \leq x \geq 0.50)$ [7] systems had impact on their $T_{\mathrm{g}}$. The higher the ratio, the higher value of $T_{\mathrm{g}}$ of these glasses.

The introduction of increasing amount of $\mathrm{Cu}_{2} \mathrm{O}$ to the structure of glasses from $x \mathrm{Cu}_{2} \mathrm{O}-y \mathrm{P}_{2} \mathrm{O}_{5}-z \mathrm{MoO}_{3}$ system where $x, y$, and $z$ were from 0 to $50 \mathrm{~mol} \%$ range, resulted in a decrease of the glass transition temperature $\left(T_{\mathrm{g}}\right)$ because of formation of weaker ionic bonds $\mathrm{Cu}^{+}-\mathrm{O}$ at the expense of strong covalent $\mathrm{P}-\mathrm{O}$ and $\mathrm{Mo}-\mathrm{O}$ bonds [4].

Increase of copper content in the structure of glasses from $(0.70-x) \mathrm{SiO}_{2}-0.30 \mathrm{Na}_{2} \mathrm{O}-x \mathrm{CuO}$ system where $x$ was from 0 to $0.2 \mathrm{~mol} \%$ resulted in decrease of their $T_{\mathrm{g}}$ [5].

The method of synthesis of glasses from $\mathrm{Cu}_{2} \mathrm{O}-\mathrm{Na}_{2} \mathrm{O}-$ $\mathrm{Al}_{2} \mathrm{O}_{3}-\mathrm{SiO}_{2}$ system also had impact on the value of the glass transition temperature $\left(T_{\mathrm{g}}\right)[8,9]$. Synthesis of these glasses using $\mathrm{Cu}^{+} / \mathrm{Na}^{+}$ion-exchange treatment enabled to regulate the valence of copper ions in the structure of such glasses. The more $\mathrm{Cu}^{+}$ions were exchanged in the course of their synthesis by ion exchange, the lower was the value of $T_{\mathrm{g}}$ of these glasses.

However, there was no information on the effect of copper on glass transition of mixed silicate-phosphate glasses.

The object of these studies was silicate-phosphate glasses from $\mathrm{SiO}_{2}-\mathrm{P}_{2} \mathrm{O}_{5}-\mathrm{K}_{2} \mathrm{O}-\mathrm{MgO}-\mathrm{CaO}-\mathrm{CuO}$ system which can act as slow-dissolving fertilizers providing plant macroelements (P, $\mathrm{K}, \mathrm{Mg}$, and $\mathrm{Ca}$ ) [10], as well as copper acting as a microelement. Copper plays an active role in many life processes of plants, such as photosynthesis, respiration, metabolism of nitrogen compounds, the formation of proteins, carbohydrate transport, and formation of RNA and DNA [11].

The purpose of this study was to investigate the influence of $\mathrm{CuO}$ content on the glass forming ability and glass transition behavior of glasses from $\mathrm{SiO}_{2}-\mathrm{P}_{2} \mathrm{O}_{5}-\mathrm{K}_{2} \mathrm{O}$ $\mathrm{MgO}-\mathrm{CaO}$ system.

\section{Experimental}

Two groups of silicate-phosphate glasses from $\mathrm{SiO}_{2}$ $\mathrm{P}_{2} \mathrm{O}_{5}-\mathrm{K}_{2} \mathrm{O}-\mathrm{MgO}-\mathrm{CaO}-\mathrm{CuO}$ differing in content of $\mathrm{P}_{2} \mathrm{O}_{5}$ and $\mathrm{CuO}$ were prepared. In both groups constant quantities of $\mathrm{K}_{2} \mathrm{O}$ and $\mathrm{SiO}_{2}$ were kept, and the increasing amount of $\mathrm{CuO}$ was introduced at the cost of decreasing amount of $\mathrm{MgO}$ and $\mathrm{CaO}$, with the constant $\mathrm{MgO} / \mathrm{CaO}$ ratio.

The silicate-phosphate glasses were produced by melting raw materials mixture, i.e., $\mathrm{SiO}_{2}, \mathrm{H}_{3} \mathrm{PO}_{4}, \mathrm{MgO}, \mathrm{K}_{2} \mathrm{CO}_{3}$, $\mathrm{CaCO}_{3}$, and $\mathrm{CuO}$ at $1450{ }^{\circ} \mathrm{C}$. Then the batch-free glasses were fritted in water. The obtained glasses were grinded to the grain size of $0.1-0.3 \mathrm{~mm}$.

Chemical composition of the synthesized glasses was determined by the X-ray fluorescence spectrometry (XRF) method, using ARL ADVANT'XP spectrometer and was presented in Table 1.

All glasses were subjected to differential scanning calorimetry (DSC) measurements conducted on Netzch STA 449 F1 Jupiter, operating in the heat flux DSC mode. Glass samples weighing $60 \mathrm{mg}$ were heated in platinum crucibles at a rate of $10^{\circ} \mathrm{C} \mathrm{min}^{-1}$ in a dry nitrogen atmosphere up to $1,100{ }^{\circ} \mathrm{C}$. Characteristic temperatures of the glass transformation effect such as the onset and the end of the glass transformation region, the glass transformation temperature $T_{\mathrm{g}}$, determined as the midpoint of the $\mathrm{c}_{\mathrm{p}}$, changes in the glass transformation region and changes of specific heat

Table 1 Chemical composition of the investigated silicate-phosphate glasses from $\mathrm{SiO}_{2}-\mathrm{P}_{2} \mathrm{O}_{5}-\mathrm{K}_{2} \mathrm{O}-\mathrm{MgO}-\mathrm{CaO}-\mathrm{CuO}$ system

\begin{tabular}{|c|c|c|c|c|c|c|c|}
\hline & \multirow[t]{2}{*}{ Name of glasses } & \multicolumn{6}{|c|}{ Content of components $/ \mathrm{mol} \%$} \\
\hline & & $\mathrm{SiO}_{2}$ & $\mathrm{P}_{2} \mathrm{O}_{5}$ & $\mathrm{~K}_{2} \mathrm{O}$ & $\mathrm{CaO}$ & $\mathrm{MgO}$ & $\mathrm{CuO}$ \\
\hline \multirow[t]{5}{*}{ Glasses with low content of $\mathrm{P}_{2} \mathrm{O}_{5}$} & $0 \mathrm{Cu} 2 \mathrm{P}$ & 40.2 & 2.1 & 6.1 & 21.3 & 30.3 & - \\
\hline & $1.5 \mathrm{Cu} 2 \mathrm{P}$ & 40.6 & 2 & 6 & 20.5 & 29.3 & 1.6 \\
\hline & $3 \mathrm{Cu} 2 \mathrm{P}$ & 39.2 & 2 & 6.1 & 20.3 & 29.2 & 3.1 \\
\hline & $6 \mathrm{Cu} 2 \mathrm{P}$ & 40.6 & 1.5 & 6.1 & 18.6 & 27.1 & 6.1 \\
\hline & $12 \mathrm{Cu} 2 \mathrm{P}$ & 40.8 & 2 & 6.1 & 15.9 & 23.2 & 12.1 \\
\hline \multirow[t]{6}{*}{ Glasses with high content of $\mathrm{P}_{2} \mathrm{O}_{5}$} & 0Cu6P & 42.6 & 6.5 & 6.7 & 23 & 21.2 & - \\
\hline & $2.5 \mathrm{Cu} 6 \mathrm{P}$ & 42.6 & 6.4 & 6.7 & 22.8 & 19 & 2.5 \\
\hline & $5 \mathrm{Cu} 6 \mathrm{P}$ & 43 & 6.5 & 6.9 & 20.3 & 18.4 & 4.9 \\
\hline & $6.5 \mathrm{Cu} 6 \mathrm{P}$ & 40 & 7 & 6.3 & 16.8 & 23.9 & 6.4 \\
\hline & 18Cu6P & 41.7 & 6.1 & 6.4 & 14.6 & 12.9 & 18.3 \\
\hline & $35 \mathrm{Cu} 6 \mathrm{P}$ & 37.5 & 5.3 & 6 & 7.7 & 8.4 & 35.2 \\
\hline
\end{tabular}


$\left(\Delta c_{\mathrm{p}}\right)$ at $T_{\mathrm{g}}$ points were determined applying the Netzsch Proteus Thermal Analysis Program (version 5.0.0.). Approximated relaxation time for the glass transformation $\tau=\left(T_{\text {end }}-T_{\text {onset }}\right) \beta^{-1}$ where $\beta$ is the heating rate [12] was evaluated.

The X-ray diffraction method (X'Pert PRO Diffractometer, Philips) was used to confirm the amorphous state of the samples.

The scanning electron microscopy (SEM) was used to find out the microstructure of the analyzed glasses.

The micro-Raman spectroscopy study of glasses was carried out on Raman Jobin-Yvon T-64000 spectrometer, using $514.5 \mathrm{~nm}$ line of Ar laser $(30 \mathrm{~mW})$ for excitant. The spectra were recorded in the $1,400-200 \mathrm{~cm}^{-1}$ range of Raman shifts.

\section{Results and discussion}

Glass forming ability

XRD results showed (Fig. 1a) that glasses with higher $\mathrm{P}_{2} \mathrm{O}_{5}$ content containing less than $18 \mathrm{~mol} \%$ of $\mathrm{CuO}$ were completely amorphous. In the case of higher content of $\mathrm{CuO}$ in the structure of these glasses, XRD diffractograms revealed the presence of $\mathrm{Cu}_{2} \mathrm{O}$ in their structure.

Results of microstructure studies of the glasses with higher content of $\mathrm{P}_{2} \mathrm{O}_{5}$ with 6.5 and $18 \mathrm{~mol} \%$ of $\mathrm{CuO}$ showed the presence of spherical inclusions in an amorphous matrix (Fig. 2a, b), which in the presence of higher content of $\mathrm{CuO}(35 \mathrm{Cu} 6 \mathrm{P})$ take the form of dendritic crystals of $\mathrm{Cu}_{2} \mathrm{O}$ (Fig. 2c).

On the other hand, in the case of glasses with a low $\mathrm{P}_{2} \mathrm{O}_{5}$ content and just $6 \mathrm{~mol} \%$ of $\mathrm{CuO}$ a weak reflex on their diffraction pattern was observed which corresponded to the beginning of copper excess precipitation from the melt (Fig. 1b).

Thus, the higher content of $\mathrm{P}_{2} \mathrm{O}_{5}$ in the structure of the studied glasses, the higher solubility limit of $\mathrm{CuO}$. This behavior suggested that copper in the silicate-phosphate glass structure formed $\mathrm{Cu}-\mathrm{O}-\mathrm{P}$ bonds.

Effect of copper as the glass modifier on structure of glasses with higher content of $\mathrm{P}_{2} \mathrm{O}_{5}$ was evidenced by Raman spectra (Fig. 3). They were characterized by bands at 960 and $1,070 \mathrm{~cm}^{-1}$ which could be assigned to $\mathrm{Si}-\mathrm{O}^{-}$ stretching vibrations in $Q^{2}, Q^{1}$ (at $960 \mathrm{~cm}^{-1}$ ), and $Q^{3}$ (at $1,070 \mathrm{~cm}^{-1}$ ) units in the silicate network. The effect of copper addition on this part of the spectrum was not very noticeable. On the other hand, the very weak band at $454 \mathrm{~cm}^{-1}$ for 0Cu6P glass sample could be attributed to symmetric stretching of $\mathrm{O}-\mathrm{P}-\mathrm{O}$ bending modes of the orthophosphate $\mathrm{PO}_{4}{ }^{3-}$ units $\left(Q^{0}\right)$ which shifted towards lower wavenumber with the increasing content of $\mathrm{CuO}$ in
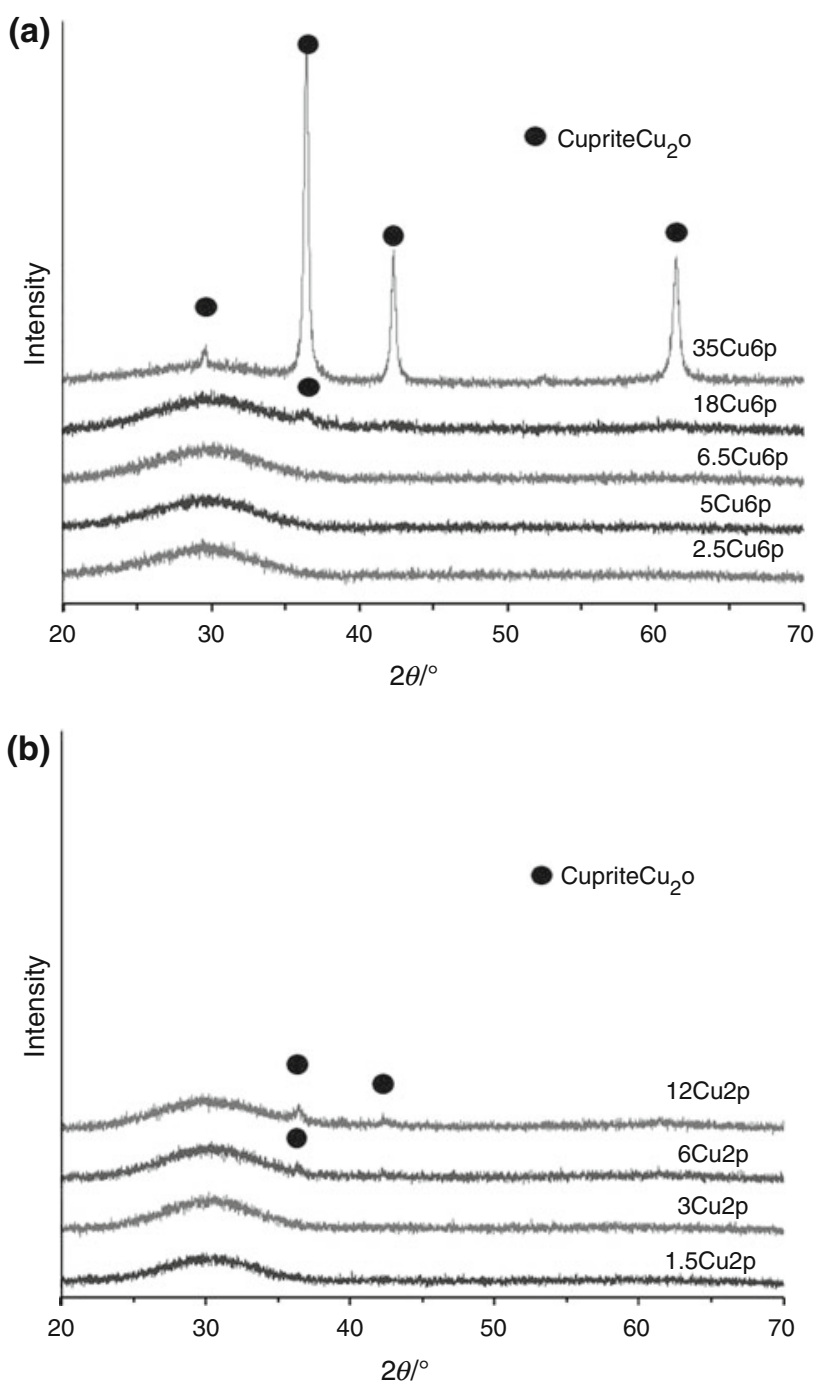

Fig. 1 XRD patterns of the glasses containing; a $6 \mathrm{~mol} \% \mathrm{P}_{2} \mathrm{O}_{5}$ and b $2 \mathrm{~mol} \% \mathrm{P}_{2} \mathrm{O}_{5}$

the glass structure, indicating depolymerization of the phosphate network [13].

Sharper than the previous one band at $588 \mathrm{~cm}^{-1}$ for 0Cu6P glass sample could be attributed to the symmetric stretching of $\mathrm{P}-\mathrm{O}^{-}$bonds of the orthophosphate units $\left(Q^{0}\right)$. This band become more distinct with the increasing content of $\mathrm{CuO}$ in the structure of analyzed glasses.

The above observations confirmed that some changes around $\mathrm{P}-\mathrm{O}-\mathrm{P}$ bonds in the structure of the considered glasses took place. They might be related to formation of $\mathrm{P}-\mathrm{O}-\mathrm{Cu}$ bonds. Formation of such bonds can be explained based on the difference of the ionicity of bonds in the oxygen bridge $\left(\Delta i_{\mathrm{G}}\right)$, which can be used to measure local chemical affinity of cations to the oxygen in oxide bridge. The higher is its value, the greater is the local chemical affinity of cations to the bridging oxygen [14]. 

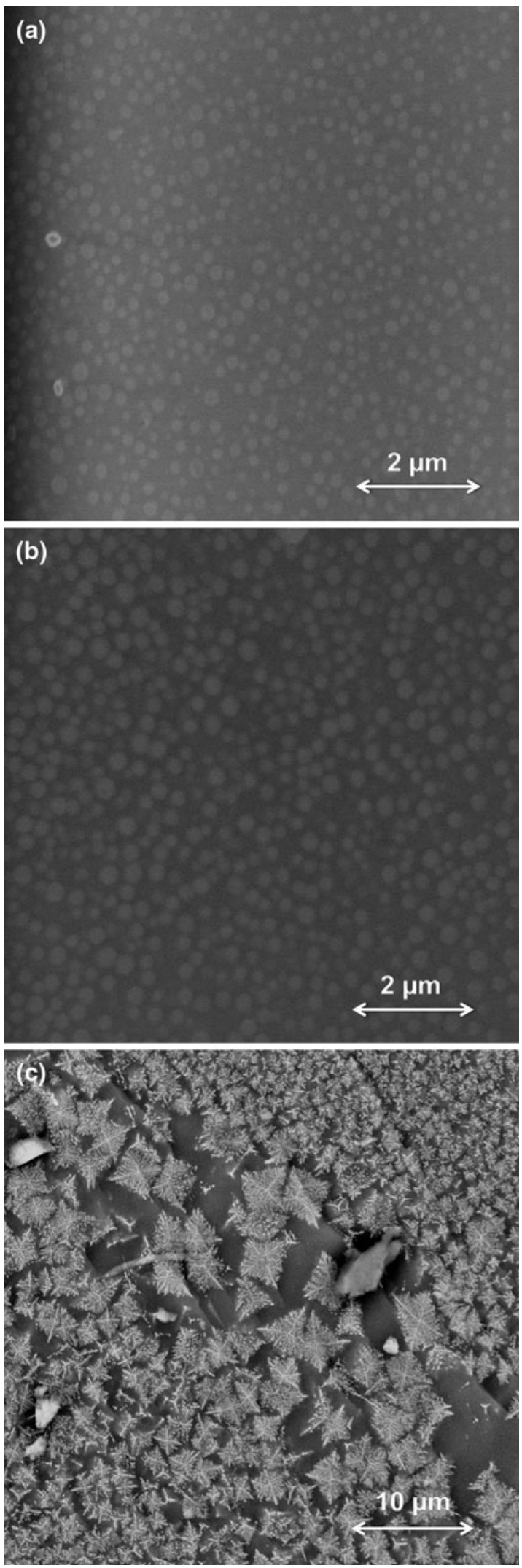

Fig. 2 SEM microphotographs of; a 6.5Cu6P, b 18Cu6P, and c 35Cu6P samples

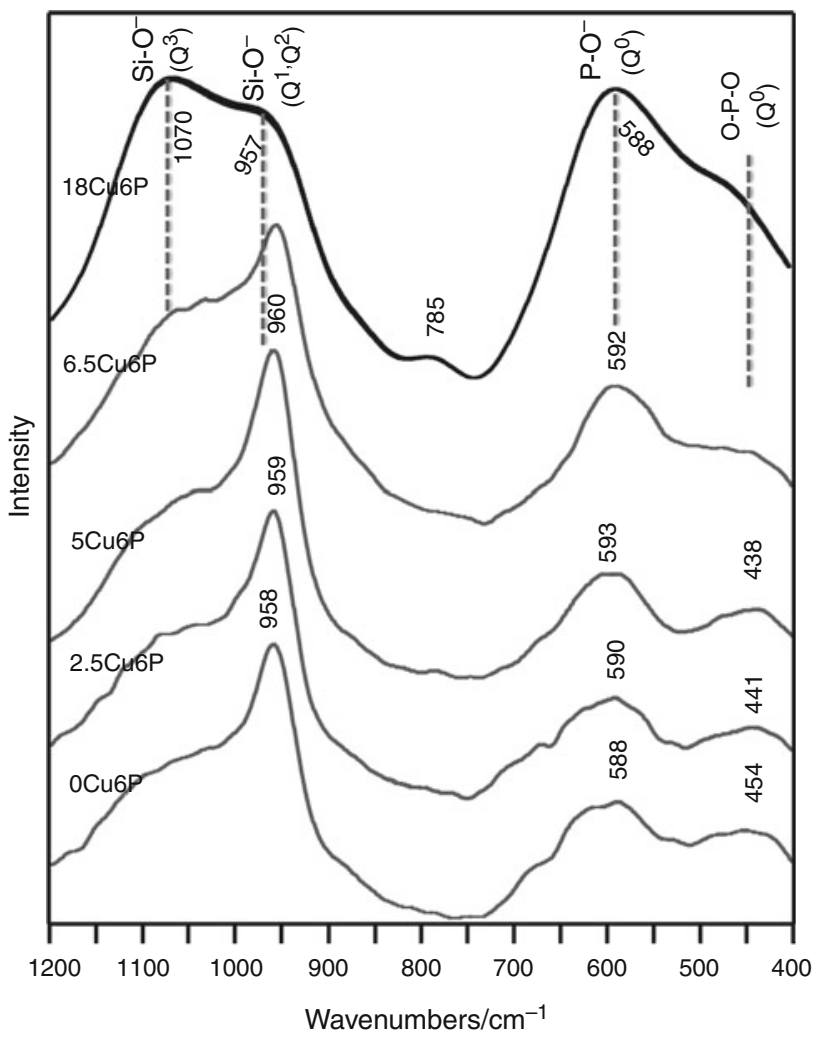

Fig. 3 Raman spectra of the silicate-phosphate glasses with 6 mol\% $\mathrm{P}_{2} \mathrm{O}_{5}$ content

Thus, the presence of copper in the structure of the studied glasses caused a break of $\mathrm{P}-\mathrm{O}-\mathrm{P}$ bonds rather than $\mathrm{Si}-\mathrm{O}-\mathrm{Si}$ bonds due to its greater affinity to phosphorus than to silicon $\left(\mathrm{Cu}^{2+}-\mathrm{O}-\mathrm{P} \Delta i_{\mathrm{G}}=0.303>\mathrm{Cu}^{2+}-\mathrm{O}-\mathrm{Si} \Delta i_{\mathrm{G}}=0.189, \mathrm{Cu}^{+}-\right.$ O-P $\left.\Delta i_{\mathrm{G}}=0.449>\mathrm{Cu}^{+}-\mathrm{O}-\mathrm{Si} \Delta i_{\mathrm{G}}=0.335\right)$.

Thermal studies

DSC curves of the studied glasses (Fig. 4a, b) showed transformation and crystallization process induced by the thermal treatment. Values of parameters characterizing the glass transformation were presented in Table 2 .

It can be noticed that, the introduction of increasing amount of copper into the structure of completely amorphous network (2.5Cu6P, 5Cu6P, 1.5 Cu2P, and 3Cu2P) caused broadening of temperature range of the transformation (i.e., increase of the relaxation time), decrease of the characteristic temperature $T_{\mathrm{g}}$ and increase of $\Delta c_{\mathrm{p}}$ accompanying the glass transformation effect. Such behavior of glasses was observed in the case of silicatephosphate glasses containing an increasing amount of $\mathrm{Fe}_{2} \mathrm{O}_{3}$ [15] and $\mathrm{B}_{2} \mathrm{O}_{3}$ [16], and it was the indication of an increasing degree of their structure relaxation. 

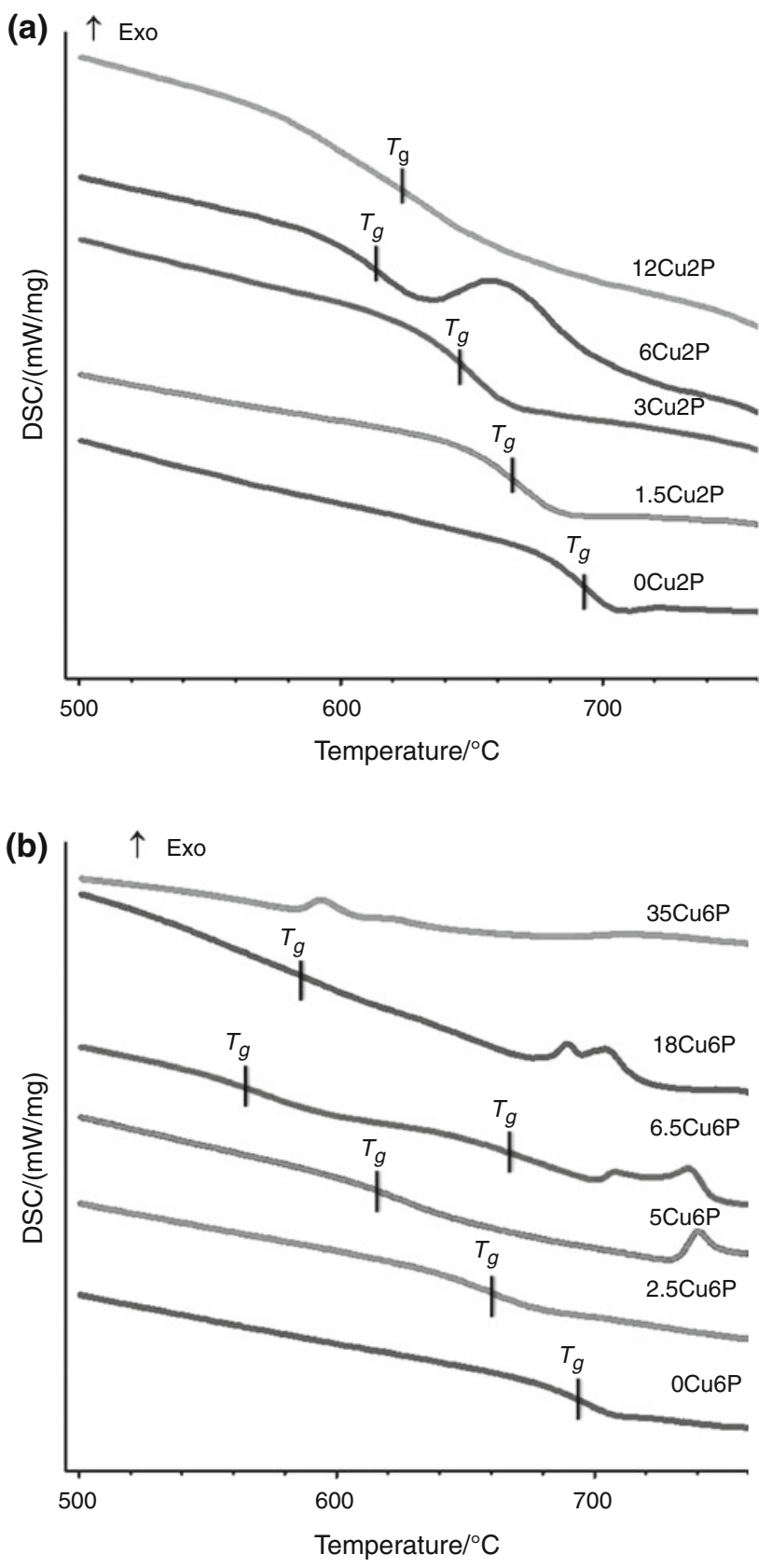

Fig. 4 DSC curves of the analyzed glasses with; a 2 mol\% $\mathrm{P}_{2} \mathrm{O}_{5}$ and b $6 \mathrm{~mol} \%$ content

On the DSC curve of glass containing $6.5 \mathrm{~mol} \%$ of $\mathrm{CuO}$ (6.5Cu6P) the double endothermic glass transformation deflection (Fig. 4b) was visible. It was related to phase separation process (liquation) of amorphous matrix of the glass, which was observed in SEM investigations (Fig. 2a, b), and which proceeded the crystallization of $\mathrm{Cu}_{2} \mathrm{O}$ (Fig. 2c).

The structural relaxation of the partially recrystallized glasses was accompanied by changes of the specific heat

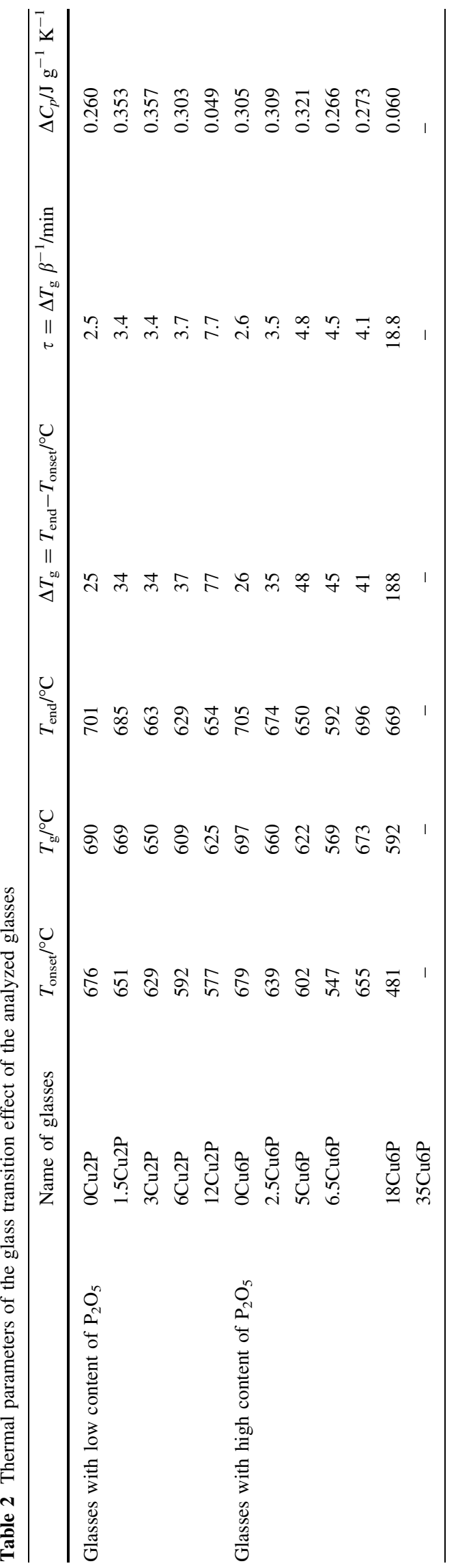


$\Delta C_{p}$ which values diminished (18Cu6P) and finally completely disappeared (35Cu6P).

The mentioned above changes of the parameters characterizing glass transformation were more visible in the glasses with higher content of $\mathrm{P}_{2} \mathrm{O}_{5}$.

Changes in the glass transformation temperature $T_{\mathrm{g}}$ could be explained based on the nature of chemical bonds in the structure of glasses. The ionicity $\left(i_{\mathrm{G}}\right)$ value of bonds of the component atoms with oxygen according to Görlich's scale [17] were applied as a parameter characterizing the strength of bonds. The more covalent character of $\mathrm{Cu}^{+2}-\mathrm{O}$ bonds $\left(i_{\mathrm{G}}=0.617\right)$ replacing the more ionic bonds such as $\mathrm{Ca}-\mathrm{O}$ bonds $\left(i_{\mathrm{G}}=0.707\right)$ and $\mathrm{Mg}-\mathrm{O}$ bonds $\left(i_{\mathrm{G}}=0.670\right)$ caused the glass structure more rigid which consequence was increasing amount of stress $\left(L_{\mathrm{Cu}+2-\mathrm{O}}=1.973\right)$ in the glass, which relaxation required less energy and hence lower values of $T_{\mathrm{g}}$ but higher value of relaxation time.

Complex multistage crystallization processes induced by the thermal treatment in the multicomponent $\mathrm{SiO}_{2}$ $\mathrm{P}_{2} \mathrm{O}_{5}-\mathrm{K}_{2} \mathrm{O}-\mathrm{MgO}-\mathrm{CaO}-\mathrm{CuO}$ glasses with variable copper content were presented in [18].

\section{Conclusions}

The appearance of glass transformation in mixed $\mathrm{SiO}_{2}$ $\mathrm{P}_{2} \mathrm{O}_{5}-\mathrm{K}_{2} \mathrm{O}-\mathrm{MgO}-\mathrm{CaO}-\mathrm{CuO}$ glasses and magnitude of parameters characterizing this effect depended on phosphorous and copper content in the glassy structure. The increasing content of phosphorous caused increase of solubility of copper in the structure of the studied glasses which was the result of formation of $\mathrm{P}-\mathrm{O}-\mathrm{Cu}$ instead of $\mathrm{P}-\mathrm{O}-\mathrm{P}$ bonds. The increasing amount of copper introduced to the amorphous matrix of glasses at the cost of decreasing amount of $\mathrm{MgO}$ and $\mathrm{CaO}$ was the reason of the increasing degree of internal strains relaxation in the glass structure which was accompanied by the decrease of transformation temperature $\left(T_{\mathrm{g}}\right)$ value and the increase of glass transformation parameters such as change of molar heat $\left(\Delta c_{\mathrm{p}}\right)$ and structural relaxation time.

Acknowledgements The study was supported by the Grant No. N R08 001006 of the Polish Ministry of Science and Higher Education.

Open Access This article is distributed under the terms of the Creative Commons Attribution License which permits any use, distribution, and reproduction in any medium, provided the original author(s) and the source are credited.

\section{References}

1. Chahine A, Et-tabirou M, Elbenaissi M, Haddad M, Pascal JL. Effect of $\mathrm{CuO}$ on the structure and properties of $(50-x / 2) \mathrm{Na}_{2} \mathrm{O}-$ xCuO- $(50-x / 2) \mathrm{P}_{2} \mathrm{O}_{5}$ glasses. Mater Chem Phys. 2004;84:341-7.

2. Shih PY, Chin TS. Effect of redox state of copper on the properties of $\mathrm{P}_{2} \mathrm{O}_{5}-\mathrm{Na}_{2} \mathrm{O}-\mathrm{CuO}$ glasses. Mater Chem Phys. 1999;60: 50-7.

3. Shih PY, Yung SW, Chin TS. Thermal corrosion behavior of $\mathrm{P}_{2} \mathrm{O}_{5}-\mathrm{Na}_{2} \mathrm{O}-\mathrm{CuO}$ glasses. J Non Cryst Solids. 1998;224:143-52.

4. Jamnicky $M$, Znášik $P$, Tunega $D$, Ingram $M D$. Glass formation and structure in the system $\mathrm{Cu}_{2} \mathrm{O}-\mathrm{P}_{2} \mathrm{O}_{5}-\mathrm{MoO}_{3}$. J Non Cryst Solids. 1995; 185:151-8.

5. Mekki A, Holland D, McConville CF. X-ray photoelectron spectroscopy study of copper sodium silicate glass surfaces. J Non Cryst Solids. 1997;215:271-82.

6. Bobkova NM, Artem'eva SA, Trusova EE. Behavior of copper oxide in silicoborate glazed glasses. Coat Enamles Glass Ceram. 2007;64(7-8):264-6.

7. Metwalli E, Karabulut M, Sidebottom DL, Morsi MM, Brow RK. Properties and structure of copper ultraphosphate glasses. J Non Cryst Solids. 2004;344:128-34.

8. Lee J, Yano T, Shibata S, Yamane M. Structure and properties of ion-exchanged $\mathrm{Na}_{2} \mathrm{O}-\mathrm{Cu}_{2} \mathrm{O}-\mathrm{Al}_{2} \mathrm{O}_{3}-\mathrm{SiO}_{2}$ glass system. J Non Cryst Solids. 1997;222:120-4.

9. Lee J, Yano T, Shibata S, Nukui A, Yamane M. EXAFS study on the local environment of $\mathrm{Cu}^{+}$ions in glasses of the $\mathrm{Cu}_{2} \mathrm{O}-\mathrm{Na}_{2} \mathrm{O}$ $\mathrm{Al}_{2} \mathrm{O}_{3}-\mathrm{SiO}_{2}$ system prepared by $\mathrm{Cu}^{+} / \mathrm{Na}^{+}$ion exchange. $\mathrm{J}$ Non Cryst Solids. 2000;277:155-61.

10. Stoch L, Stoch Z, Wacławska I. Silicate glass fertilizer. Patent PL 185229 B1. 2003 [Polish].

11. Krzywy E. Fertilization of soils and plants. Szczecin: University of Agriculture; 2000 [Polish].

12. Soliman AA, Kashif I. Copper oxide content dependence of crystallization behavior, glass forming ability, glass stability and fragility of lithium borate glasses. Phys B. 2010;405:247-53.

13. Agathopoulos S, Tulyaganov DU, Ventura JMG, Kannan S, Saranti A, Karakassides MA, Ferreira JMF. Structural analysis and devitrification of glasses based on the $\mathrm{CaO}-\mathrm{MgO}-\mathrm{SiO}_{2}$ system with $\mathrm{B}_{2} \mathrm{O}_{3}, \mathrm{Na}_{2} \mathrm{O}, \mathrm{CaF}_{2}$ and $\mathrm{P}_{2} \mathrm{O}_{5}$ additives. J Non Cryst Solids. 2006;352:322-8.

14. Stoch L. Crystallochemical aspects of structure controlled processes in oxide glasses. Optica Applicata. 2008;XXXVIII(1): 225-35.

15. Wacławska I, Szumera M. Thermal behaviour of Fe-doped silicate-phosphate glasses. J Therm Anal Calorim. 2010;101:423-7.

16. Szumera M, Wacławska I, Olejniczak Z. Influence of $\mathrm{B}_{2} \mathrm{O}_{3}$ on the structure and crystallization of soil active glasses. J Therm Anal Calorim. 2010;99:879-86.

17. Görlich E. The effective charges and the electronegativity. Kraków: Polish Academy of Art and Science; 1997.

18. Sułowska J., Wacławska I., Szumera M., Olejniczak Z. Characterization of thermally induced of crystalline phases in $\mathrm{CuO}$ containing silicate-phosphate glasses. J Therm Anal Calorim. 2011. doi 10.1007/s10973-011-1988-5. 